\title{
Ectopic Thyroid Tissue With a Rare Vascular Variation
}

\author{
Tejido Tiroideo Ectópico con una Rara Variación Vascular \\ ${ }^{*, * * *}$ T. Ramesh Rao; ${ }^{* * * * * * *}$ Balakrishnan, R.; ${ }^{* * * *}$ Prakashchandra Shetty \& ${ }^{* * *}$ Suresh, R.
}

RAMESH, R. T.; BALAKRISHNAN, R.; PRAKASHCHANDRA, S. \& SURESH, R. Ectopic thyroid tissue with a rare vascular anomaly. Int. J. Morphol., 25(1):121-124, 2007.

SUMMARY: Awareness of the variations and anomalous existence of some structures serve as useful guide for both in studies of human anatomy and in clinical practice today. Identification of ectopic thyroid tissue and variations in origin, number and course of the branches of the superior thyroid artery are of significant practical importance for the general, vascular surgeons and radiologist. Angiographic images with such vascular patterns may lead to confusion in interpretation. The relations of these vessels with the other structures are important for accurate diagnostic and invasive techniques and to prevent further complications during surgical interventions. In our routine dissections with the purpose of preparation of the teaching and museum specimens, it was observed that in one of the elderly male cadaver showed median thyroid tissue at a site other than in its usual pretracheal region. It was situated in the median plane extending from the hyoid bone to the front of cricoid cartilage. Normal thyroid gland in the pretracheal region was absent. Added to this rare anomaly a vascular anomaly was found in the same ectopic thyroid tissue. Solely the superior thyroid arteries supplied this median thyroid tissue. The inferior thyroid arteries were found to be absent on both sides supplying this median thyroid tissue.

KEY WORDS: Ectopic thyroid tissue; Vascular variation; Midline cervical mass.

\section{INTRODUCTION}

Abnormalities in the embryologic development and migration of the thyroid gland can result in ectopic thyroid tissue, which may occur on the midline in any position from the base of the tongue to the mediastinum. Although ectopic thyroid tissue may be asymptomatic, local obstructive, hemorrhagic or other complications may occur (Walling, 1987). Ectopic thyroid usually occurs along the path of descent of the developing thyroid primodium from the foramen caecum, commonest being lingual (Batsakis et al., 1996, Shehzad et al., 2001, Arancibia et al., 1998,) followed by sublingual are rather less frequent (Batsakis et al.) and in the anterior midline of neck at or below the level of the hyoid bone (Damiano et al., 1996).

Several reports shows the presence of ectopic thyroid tissue in different regions of the body other than abnormal migration of the thyroid gland such as, in the submandibular region (Sambalo-Cabrer et al., 1996), lateral aspect of the neck (Caccetta et al., 2005), heart (Casanova et al., 2000) duodenal wall (Takahashi et al., 1991), gall bladder (Harach,
1998) and in porta hepatis (Ghanem et al., 2003). We present a rare case of ectopic thyroid tissue with vascular anomaly in one of the middle aged male cadaver.

\section{CASE RELATED}

During routine dissection in one of the middle age male cadaver done at Department of Anatomy, Kasturba Medical College, Manipal, an ectopic thyroid tissue was found in the sub hyoid region (Figs. 1 and 2). This cosmetically unacceptable ovoid mass of thyroid tissue was present in the midline overlying the thyrohyoid membrane, thyroid cartilage and cricoid cartilage. It was measuring about $4.8 \mathrm{~cm}$ in length, $2.6 \mathrm{~cm}$ in breadth and $1 \mathrm{~cm}$ in thickness. A sub hyoid ectopic thyroid gland is a rare anomaly, and is a result of incomplete descent and bifurcation of the thyroid anlage. A normally placed thyroid gland in pretracheal region was not found.

* Department of Para clinical Sciences, Faculty of Medical Sciences, The University of the West Indies, St. Augustine, Trinidad.

** Department of Ear, Nose and Throat, Kasturba Medical Hospital, India.

**** Department of Anatomy, Kasturba Medical College, MAHE, Manipal, Udupi District - 576104, Karnataka State, India.

${ }^{* * * *}$ Department of Pre-clinical Sciences, Faculty of Medical Sciences, The University of the West Indies, St. Augustine, Trinidad. 


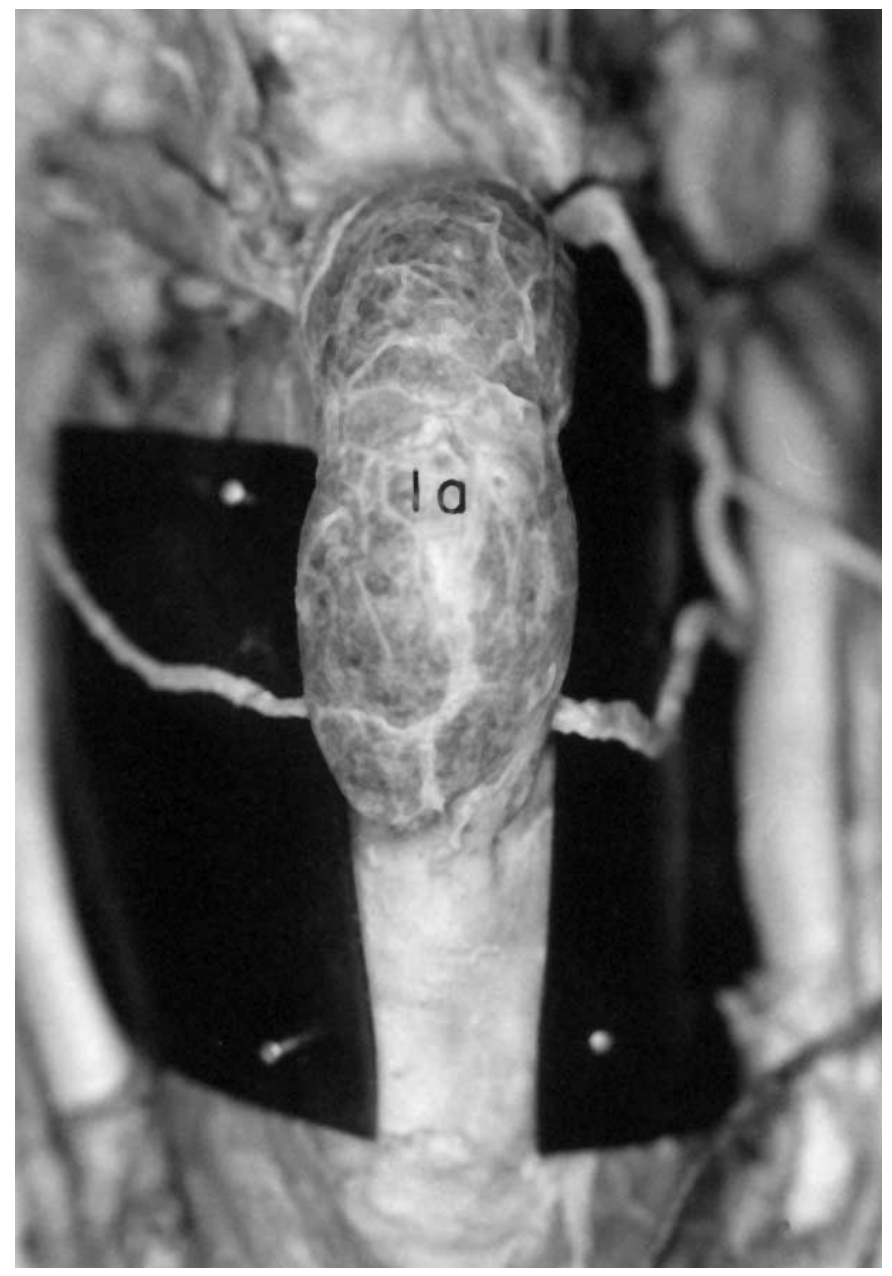

Fig. 1. Median thyroid tissue.

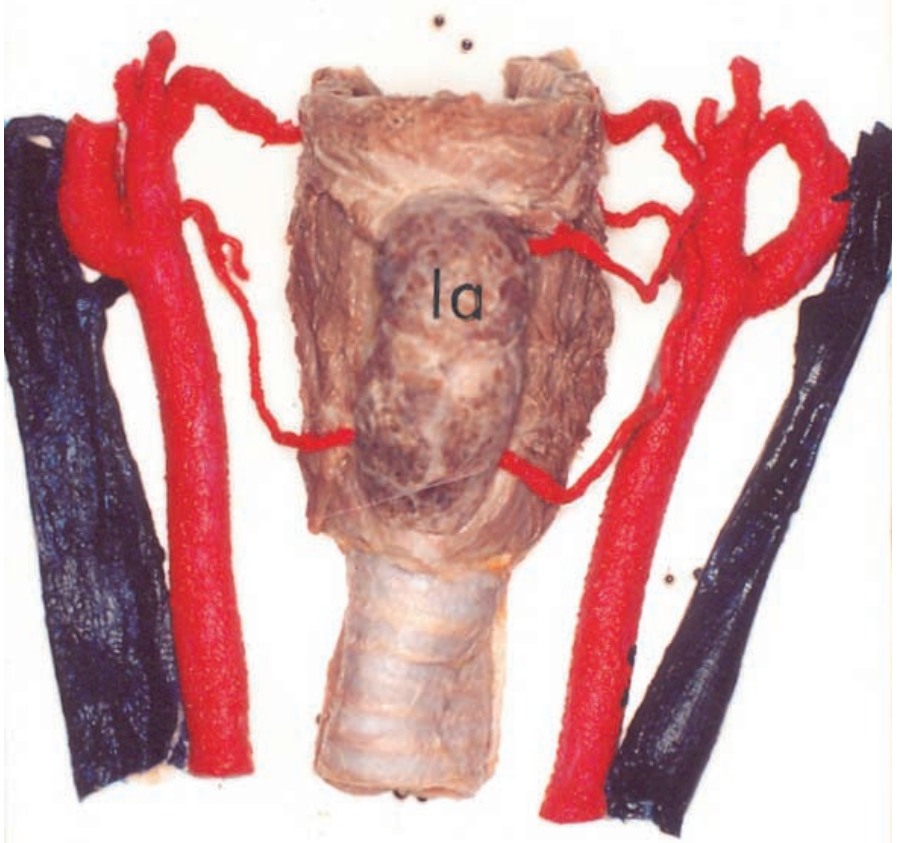

Fig. 2. Median thyroid tissue.
Added to this rare anomaly, a vascular variation was found in the same cadaver supplying the ectopic thyroid tissue (Fig. 3). Only the superior thyroid arteries supplied this median thyroid tissue. The superior thyroid arteries from its normal origin, on both sides ran forwards and downwards, and divided into superior and inferior branches, which entered the gland through the respective poles of the median thyroid tissue. The inferior thyroid arteries were found to be absent on both sides supplying this median thyroid tissue.

\section{DISCUSSION}

Ectopic thyroid tends to increase in size when hormonal demands increase, like puberty, pregnancy, stress etc. It usually presents as asymptomatic mass in the base of the tongue or anterior neck. A lingual thyroid may cause dysphagia and feeling of lungs in throat which may increase during period of stress. Sudden increase in size may also occur due to hemorrhage into the gland. Patients may present with features of hypothyroidism of the gland is not able to cope up with the hormonal needs. Hence management may include hormonal supplementation or surgery. Surgical treatment of symptomatic ectopic thyroid depends on presence or absence of normal pretracheal functioning thyroid. If the later were present surgery for ectopic thyroid would be simple excision of the ectopic tissue. If normal functioning thyroid is absent, the ectopic thyroid tissue has to be presumed. The gland may either be excised or implanted as thin slices into the scar or rectus abdominis muscle or the ectopic gland may be translocated along with the vascular pedicle into the lateral cervical gutter. The latter technique needs knowledge of the anatomy of such ectopic glands and its vascular aberrations. Batsakis et al., reveal that although the exact pathogenesis of this ectopic, accessory thyroid tissue is not known, it generally originates from epithelial tissue of non-obliterated thyroglossal duct. Bergman \& Thomson (1988) reported that as a rule the two lateral lobes are almost equally well developed, but occasionally they are very unequal in size, and in rare cases one lobe may be absent. The isthmus varies greatly in size and is frequently absent.

Several earlier studies showed that presence of ectopic thyroid tissue, in different location along the path of migration from the foramen caecum to the mediastinum, which may form aberrant masses of thyroid tissue, cysts, fistula or sinuses, usually in the midline and this condition may remain unnoticed until puberty. (Williams et al., 1995, Damiano et al.; Ueda et al., 1998; O’Neill et al., 1998; Anson,1966, Soliman, 1988). 


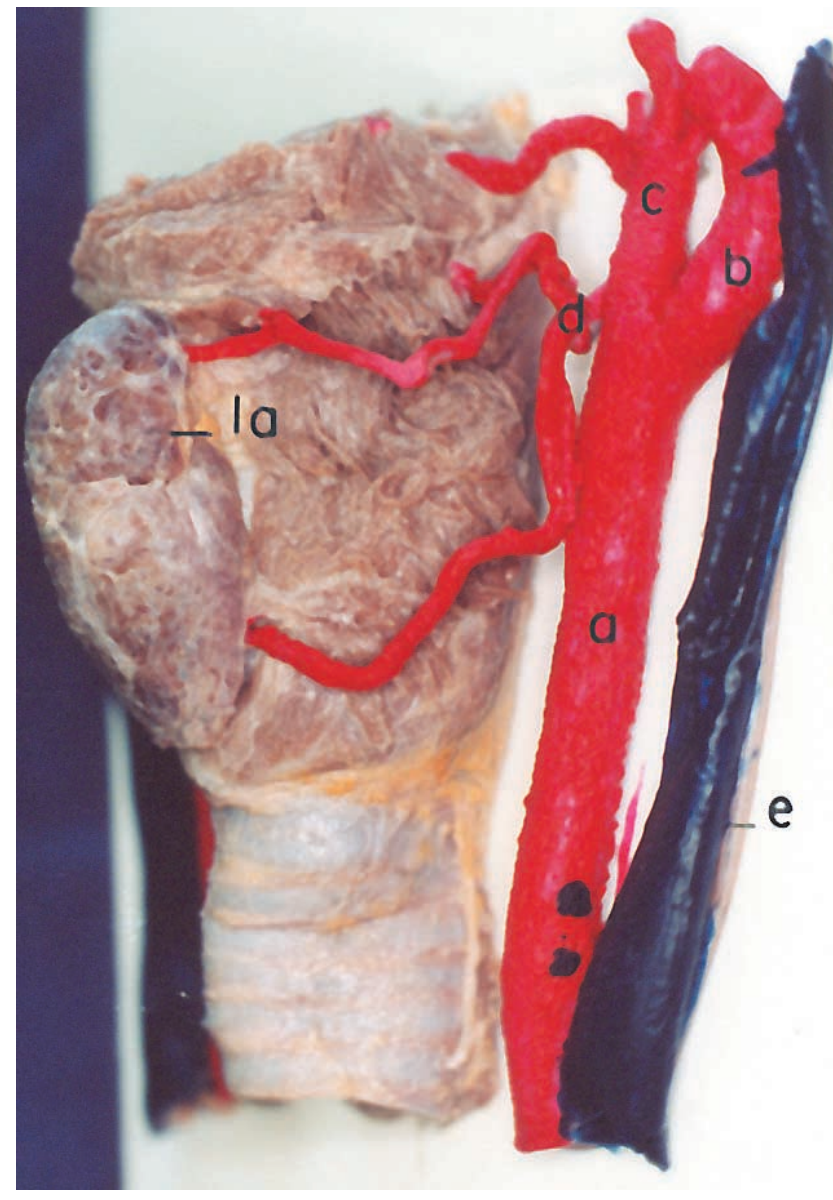

Fig. 3. 1a. Median thyroid tissue; a. Common carotid artery; b. Internal carotid artery; c. External carotid artery; d. Superior thyroid artery; e. Internal jugular vein.

Hazarika et al. (1985) reported that ectopic thyroid tissue can also be present at other sites like intra-tracheal and intraoesophageal. Lingual thyroid is the most common location for ectopic thyroid tissue, accounting for $90 \%$ of the cases. The prevalence of lingual thyroid is 1 in 100000 , and it is more common in women, with a female to male ration ranging between 3:1 to 7:1 (Arancibia et al.). In 70$75 \%$ of patients with lingual thyroid there is no ectopic thyroid tissue present in the pretracheal position (Neinas et. al., 1973). There is little information available in the literature on vascular anomaly of the ectopic thyroid tissue.

Bergma \& Thomson, reported that superior thyroid artery is generally considered to be present in $100 \%$ of cases and its absence has only been reported once. An unusually large superior thyroid artery may replace the contra lateral vessels or the inferior thyroid artery. Inferior thyroid artery has been reported absent or doubled. The inferior thyroid artery when usually small or absent may be replaced or supplemented by thyroidea ima artery. Weiglain (1996) reported a case wherein the right inferior thyroid artery was replaced by an artery branching off from the right internal thoracic artery and the left inferior thyroid artery was replaced by an artery, a branch of vertebral artery. During routine dissection Moriggl \& Oturm (1996) found out the absence of both inferior thyroid arteries and right superior thyroid artery in a 7-year old female donor. In this case a large lowest thyroid artery took origin from the left internal thoracic artery to supply the thyroid gland. In our studies, both inferior thyroid arteries were absent and both superior thyroid arteries solely supplied the sub hyoid ectopic thyroid tissue by giving superior and inferior branches.

\section{CONCLUSION}

Knowledge of ectopic thyroid and its vascular aberration is essential in routine surgical practice. Proper identification of these vessels is very important in order to avoid major complications especially during head and neck surgery. Surgeons must be aware of possible variations of the Ectopic thyroid tissue and its vascular anomaly and should be considered in the differential diagnosis of swellings involving tumors of the salivary glands.

RAMESH, R. T.; BALAKRISHNAN, R.; PRAKASHCHANDRA, S. \& SURESH, R. Tejido tiroideo ectópico con una rara variación vascular. Int. J. Morphol., 25(1):121-124, 2007.

RESUMEN: Conocer la existencia de variaciones y anomalías de algunas estructuras, sirve usualmente como guía para estudios de anatomía humana y práctica clínica. La identificación de tejido tiroideo ectópico y variaciones en origen, número y curso de ramas de la arteria tiroidea superior son, por lo general, de importancia práctica significativa para cirujanos vasculares y radiólogos. Imágenes angiográficas con tales patrones vasculares pueden llevar a confusión en su interpretación. La relación de estos vasos con otras estructuras son importantes en un diagnóstico acucioso, en técnicas invasivas y para prevenir complicaciones durante intervenciones quirúrgicas. En una disección de rutina, con el propósito de preparar piezas anatómicas de museo para la enseñanza, se observó en un cadáver de sexo masculino, tejido tiroideo mediano en un sitio diferente a la región pretraqueal. Estaba situado en el plano mediano extendiéndose desde el hueso hiodes a la parte anterior del cartílago cricoides. La glándula tiroides normal en la región pretraqueal estuvo ausente. Agregada a estainusual variación, una rara anomalía vascular fue encontrada en el mismo tejido tiroideo ectópico, sólo las arterias tiroideas superiores irrigaban este tejido tiroideo mediano. No se encontraron arterias tiroideas inferiores irrigando este tejido.

PALABRAS CLAVE: Tejido tiroideo ectópico; Variación vascular; Masa cervical mediana. 


\section{REFERENCES}

Anson, B. J. Morris' Human Anatomy. $12^{\text {th }}$ ed. Barry J. Anson. The endocrine glands and Unclassified Organs , 1966. p. 1550 .

Arancibia, P.; Véliz, J.; Barría, M. \& Pineda, G. Lingual thyroid: report of three cases. Thyroid, 8:1055-7, 1998.

Batsakis, J. G.; El-Naggar, A. K. \& Luna, M. A. Thyroid gland ectopias. Ann. Otol. Rhinol. Laryngol., 105:996-1000, 1996.

Bergman, R. A.; Thomson, S. A.; Afifi, A. K. \& Saadeh, F. A. Compendium of Human Anatomic Variation In: Endocrine system, Urban and Schwarzenber, Baltimore, 1988. p. 175.

Casanova, J. B.; Daly, R. C.; Edwards, B. S.; Tazelaar, H. D. \& Thompson, G. B. Intracardiac ectopic thyroid. Ann. Thorac. Surg., 70:1694-6, 2000.

Caccetta, T. P.; Kumar, A. F. \& Ishak, H. F. Anz. J. of Surgery, 75(12):1123-4, 2005.

Damiano, A.; Glickman, A. B.; Rubin, J. S. \& Cohen, A. F. Ectopic thyroid tissue presenting as a midline neck mass. Int. J. Pediatr. Otorhinolaryngol., 34(1-2):141-8, 1996.

Ghanem, N.; Bley, T.; Altehoefer, C.; Hogerle, S. \& Langer, M. Ectopic thyroid gland in the porta hepatic and lingua. Thyroid, 13:503-7, 2003.

Harach, H. R. Ectopic thyroid tissue adjacent to the gallbladder. Histopathology, 32:90-1, 1998.

Hazarika, P.; Ravikumar, V. \& Nayak, R. G. Intralaryngotracheal Thyroid (Letter). Ear, Nose and Throat J., 64: 44-7, 1985.

Moriggl, D. \& Oturm, W. Absence of three thyroid arteries replaced by an unusual lowest thyroid artery (Arteria thyroidea ima): a case report. Surg. Radiol. Anat., 10(2): 147-50, 1996.

Neinas FW, Gorman CA, Devine KD, Woolner LB. Lingual thyroid. Clinical characteristics of 15 cases. Ann. Intern. Med., 79:205-10, 1973.

O’Neill, J. A.; Rowe, M. I.; Fonkalsrud, E. W. \& Coran, A. G. Pediatric Surgery. V. 1. In: Thyroid / Parathyroid by Norman W. Thompson, James D. Geiger, Copyright by Mosby - Year Book, Inc., 1998.
Sambalo-Cabrer, I. F.; Real, J. M.; Ricart, W.; Barbas, J. F.; Olle, M. \& Ternel, J. Ectopic thyroid tissue presenting as a submandibular mass. Head Neck, 18(1):87-90, 1996.

Shehzad, B.; William, H.W. \& Cooper, D. S. Ectopic lingual thryroid masquerading as thyroid cancer metastases. $J$. of Clinical Endocrinology \& Metabolism. 86(1):392-5, 2001.

Soliman, S. M. Thyroid cartilage at the suprasternal notch with low situated thyroid gland. J. Laryngol. Otol. 102(5):476$8,1988$.

Takahashi, T.; Ishikura, H.; Kato, H.; Tanabe, T. \& Yoshiki, T. Ectopic thyroid follicles in the sub mucosa of the duodenum. Virchows Arch. A. Pathol. Anat. Histopathol., 418:547-50, 1991.

Ueda, D.; Yoto, Y. \& Sato, T. Ultrasonic assessment of the lingual thyroid gland in children. Pediatr. Radiol., 28:1268,1998 .

Walling, A. D. Ectopic thryroid tissue. Am. Family Physician, 36(3):147-50, 1987.

Weiglain, A. A rare variant of thyroid gland vascularization. Surg. Radiol. Anat., 10(3):233-5, 1996.

Williams, P. L.; Bannister, L. H.; Berry, M. Gray's Anatomy In: Embryology and Development. $38^{\text {th }}$ Ed. Churchill Livingstone, Edinburg, 1995. p176.

Correspondence Addresses:

Dr. T. Ramesh Rao

Department of Paraclinical Sciences

Faculty of Medical Sciences,

The University of the West Indies

St. Augustine

TRINIDAD

Tel. - 001-868-645-2640, Extn. 5001

Fax: - 001-868-662-1472

Email: varun1195@yahoo.com

Received: 22-11-2006

Accepted: 28-12-2006 